$H$ ducreyi was isolated only rarely with conventional media and always from people with genital ulcers, which were usually acquired abroad. The Sheffield medium has been tested in the tropics, and its lack of sensitivity suggests that it is detecting organisms other than $\mathrm{H}$ ducreyi. ${ }^{20}$

The Sheffield results thus seem to have been an artefact, and chancroid remains a very rare imported condition in Britain. As long as British facilities to treat genital ulcers remain free and easily accessible this state of affairs is likely to continue.

Consultant in Genitourinary Medicine,

A MINDEL

Middlesex Hospital,

London WIN 8AA

1 Duncan MO, Bilgeri YR, Fehler HG, Ballard RC. The diagnosis of sexually acquired genital ulcerations in black patients in Johannesburg. South Africa Joumal of Sexually Transmitted Diseases 1981;1:20-3.

2 Nsanze H, Fast M, D'Costa LJ, Tukei P, Curran J, Ronald AR. Genital ulcers in Kenya: a clinical and laboratory study. British fournal of Venereal Disease 1981;57:378-81.

3 Meheus A, Van Dyck E, Ursi JP, Ballard RC, Piot P. Etiology of genital ulcerations in Swaziland. Sex Trans Dis 1983;10:33-5.

4 Taylor DN, Duangmani C, Suvongse C, et al. The role of Hemophilus ducreyi in penile ulcers in Bangkok, Thailand. Sex Trans Dis 1984;11:148-51.
5 Adler MW. ABC of sexually transmitted diseases. London: British Medical Association, 1984:19-20. 6 Lykke-Olesen L, Larsen L, Pedersen TG, Gaarslev K. Epidemic of chancroid in Greenland 1977-1978. Lancet 1979;i:654-5.

7 Nayyer KC, Stolz E, Michel ME. Rising incidence of chancroid in Rotterdam. Epidemiological, clinical, diagnostic, and therapeutic aspects. British fournal of Venereal Disease 1979;55:439-41.

8 Blackmore CA, Limpakarnianarat K, Rigau-Perez JG, et al. An outbreak of chancroid in Orange County, California: descriptive epidemiology and disease control measures. I Infect Dis 1985;151:840-4.

9 Anonymous. Chancroid-Massachusetts. MMWR 1985;34:711-8.

10 Becker TM, DeWitt W, Van Dusen G. Hemophilus ducrevi infection in South Florida. A rare disease on the rise? South Med F 1987;80:182-4.

11 Schmid GP, Sanders LL, Blount JH, Alexander ER. Chancroid in the United States: re-establishment of an old disease. FAMA 1987;258:3265-8.

12 Plummer FA, D'Costa LJ, Nsanze H, Dylewski J, Karasira P, Ronald AR. Epidemiology of chancroid and Haemophilus ducreyi in Nairobi, Kenya. Lancet 1983;ii:1293-5.

13 Hafiz S, Kinghorn GR, McEntegart MG. Chancroid in Sheffield: a report of 22 cases diagnosed by isolating Haemophilus ducreyi in a modified medium. British fournal of Venereal Disease 1981;57:382-6.

14 Kinghorn GR, Hafiz S, McEntegart MG. Pathogenic microbial flora of genital ulcers in Sheffield with particular reference to herpes simplex virus and Hemophilus ducreyi. British fournal of Venereal Disease 1982;58:377-80.

15 Hafiz S, McEntegart MG, Kinghorn GR. Sheffield medium for cultivation of Haemophilus ducreyi. British fournal of Venereal Disease 1984;60:196-8.

16 McEntegart MG, Hafiz S, Kinghorn GR. Haemophilus ducreyi infections: time for reappraisal. Journal of Hygiene 1982;89:467-8.

17 Arya OP, Cupit P, Dundon MB, Bartzokas CA. Chancroid in Liverpool. Genitourin Med 1988;64:66.

18 Mallard RH, Macaulay ME, Riodeu T, Chowdhury FH, Chandiok S, Bhattacharyya MN Haemophilus ducreyi infection in Manchester. Lancet 1983;ii: 283.

19 Diaz-Mitoma F, Benningen G, Slutchuk M, Ronald AR, Branham RC. Etiology of nonvesicular genital ulcers in Winnipeg. Sex Trans Dis 1987;14:33-6.

20 Piot P, Slootmans L, Nsanze H, Ronald AR. Isolating Haemophilus ducreyi. Lancet 1983;ii: $909-10$.

\title{
Causes of the haemolytic uraemic syndrome
}

\author{
It might be verocytotoxin produced by Escherichia coli
}

The haemolytic uraemic syndrome is the commonest cause of acute renal failure in children in Britain and is increasingly recognised in adults. ${ }^{12}$ Sporadic cases and small epidemics occur, ${ }^{34}$ commonly in the summer months. The syndrome is characterised by a microangiopathic haemolytic anaemia, thrombocytopenia, and renal failure. ${ }^{5}$ Most affected children (up to $90 \%$ ) have the "classic" syndrome with prodromal diarrhoea that is usually bloody. Many causes of the syndrome, mainly infectious agents, ${ }^{5-8}$ have been proposed, but recently a strong association has been found between the haemolytic uraemic syndrome and enteric infection with verocytotoxin-producing Escherichia coli..$^{9}{ }^{10}$ These organisms, also known as enterohaemorrhagic $E$ coli, are associated with clinical conditions ranging from self limiting diarrhoea to bloody diarrhoea with haemorrhagic colitis and the haemolytic uraemic syndrome. ${ }^{811}$ Verocytotoxin (Shiga-like toxin) is also produced by Shigella dysenteriae type $1 .^{12}$

The toxin consists of a biologically active subunit A linked to $\mathrm{B}$ subunits, ${ }^{13}$ which bind to specific receptors. ${ }^{14}$ Once attached to the cell surface subunit $A$ enters the cell and inhibits protein synthesis by inactivating 60s ribosomal subunits, which leads to cell death. ${ }^{15}$

An infective cause for the haemolytic uraemic syndrome has long been suspected because of its seasonal distribution, the occurrence of small epidemics and person to person transmission, and its common association with prodromal gastrointestinal illness. Much of the pathology of the syndrome suggests that it is associated with a toxin, ${ }^{816}$ and evidence to implicate verocytotoxin has accumulated. Infection with verocytotoxin-producing $E$ coli was found in almost $90 \%$ of patients with the classic haemolytic uraemic syndrome studied in Canada ( $\mathrm{N}$ Ish-Shalom et al, international symposium and workshop on VTEC [verocytotoxin-producing $E$ coli infections, Toronto, 1987), almost three fifths of those studied in the United States, ${ }^{17}$ and a third of those studied in Britain. ${ }^{18}$ The two pathogens most consistently associated with the syndrome-some serotypes of $E$ coli and $S h$ dysenteriae-both produce high concentrations of verocytotoxin. ${ }^{19}$ Verocytotoxin is found in faeces, and patients with the haemolytic uraemic syndrome may develop specific antibodies that neutralise the toxin. ${ }^{10}$ Verocytotoxin has not been detected in patients' blood or tissues, but this is true of many diseases associated with toxins.

In vitro studies support the hypothesis that verocytotoxin may be important in the haemolytic uraemic syndrome. The causative agent must be able to damage endothelial cells, ${ }^{5-7}$ and verocytotoxin has now been shown to be cytopathic to cultured endothelial cells. ${ }^{2021}$ It also causes the release of endothelial cell factor VIII (J Kavi et al, international workshop on VTEC infections, Toronto, 1987). These findings might explain the increase in large multimetric forms of factor VIII that is found in the plasma of patients with the acute phase of the haemolytic uraemic syndrome and returns to normal on clinical recovery. ${ }^{22}$ These large forms of factor VIII promote platelet aggregation, thrombotic lesions, and thrombocytopenia. A potent platelet aggregating activity, which is independent of factor VIII, is also known to develop on incubating verocytotoxin with normal plasma. ${ }^{23}$ Although the red cell fragmentation and haemolysis seen in the haemolytic uraemic syndrome are widely believed to be caused by mechanical injury, verocytotoxin might be the cause because red cell membranes have recently been found to contain specific verocytotoxin receptors. ${ }^{1+}$ Animal studies also suggest that verocytotoxin might be important in the haemolytic uraemic syndrome: verocytotoxin given intravenously in rabbits produces gross and ultrastructural changes similar to those seen in the haemolytic uraemic syndrome ( $\mathrm{S}$ Richardson et al, international workshop on VTEC infections, Toronto, 1987).

These advances raise as many questions as they answer, and a clear model to explain how verocytotoxin is associated with the haemolytic uraemic syndrome is still awaited. But 
unravelling the association should increase our understanding of renal vascular pathology in general and might lead to a rational approach to preventing and managing the haemolytic uraemic syndrome.

J KAVI

Registrar

Public Health Laboratory,

Coventry and Warwickshire Hospital,

Coventry CV1 4FH

R WISE

Consultant

Department of Medical Microbiology,

Dudley Road Hospital,

Birmingham B18 7QH

1 White DJ, Yong F, McKendrick MW. Haemolytic uraemic syndrome in adults. $\mathrm{Br}$ Med $\mathcal{J}$ 1988;296:899.

2 Carter AO, Borczyk AA, Carlson JAK, et al. A severe outbreak of Escherichia coli 0157:H7 associated hemorrhagic colitis in a nursing home. $N$ Engl F Med 1987;317:1496-500.

3 Levin M, Barratt TM. Haemolytic uraemic syndrome. Arch Dis Child 1984;59:397-400.

4 Taylor CM, White RHR, Winterborn MH, Rowe B. Haemolytic-uraemic syndrome: clinical experience of an outbreak in the West Midlands. Br Med F 1986;292:1513-6.

Fong JSC, de Chandarevian J-P, Kaplan BS. Hemolytic-uremic syndrome: current concepts and management. Pediatr Clin North Am 1982;29:835-56.

6 Drummond KN. Hemolytic uremic syndrome - then and now. $N$ Engl $f$ Med 1985;312:116-8.

7 Kaplan BS, Proesmans W. The hemolytic uremic syndrome of childhood and its variants. Semin Hematol 1987;24:148-60.

8 Anonymous. Unravelling HUS [Editorial]. Lancet 1987;ii:1437-9.

9 Karmali MA, Steele BT, Petric M, Lim C. Sporadic cases of haemolvtic-uraemic syndrome associated with faecal cytotoxin and cytotoxin-producing Fscherichia coli in stools. Lancet 1983;i:619-20

10 Karmali MA, Petric M, Lim C, Fleming PC, Arbus GS, Lior H. The association between idiopathic hemolytic uremic syndrome and infection by verotoxin-producing Escherichia coli. f Infect Dis 1985;151:775-82

11 Symonds J. Haemorrhagic colitis and Escherichia coli 0157 -a pathogen unmasked. Br Med $\mathcal{J}$ $1988 ; 296: 875-6$

12 O'Brien AD, Lively TA, Chen ME, Rothman SW, Formal SB. Escherichia coli 0157:H7 strains associated with haemorrhagic colitis in the United States produce a Shigella dysenteriae 1 (Shiga) like cytotoxin. Lancet 1983;i:702.

13 Otsnes S, Reisbig R, Eiklid K. Subunit structure of Shigella cytotoxin. 7 Biol Chem $1981 ; 256: 8732-8$.

14 Lingwood CA, Law H, Richardson S, et al. Glycolipid binding of purified and recombinant Escherichia coli produced verocytotoxin in vitro. $\mathcal{F}$ Biol Chem 1987;262:8834-9.

15 O'Brien AD, Holmes RK. Shiga and shiga-like toxins. Microbiol Rev 1987;51:206-20.

16 Koster F, Levin J, Walker L, et al. Hemolytic-uremic syndrome after shigellosis: relation to endotoxemia and circulating immune complexes. N Engl f Med 1978;298:927-33.

17 Neill MA, Tarr PI, Clausen CR, Christie DL, Hickman RO. Escherichia coli 0157:H7 as the predominant pathogen associated with the hemolytic uremic syndrome: A prospective study in the Pacific Northwest. Pediatrics 1987:80:37-40.

18 Scotland SM, Rowe B, Smith HR, Willshaw GA, Gross RJ. Verocytotoxin-producing strains of Escherichia coli from children with haemolytic uraemic syndrome and their detection by specific DNA probes. I. Med Microbiol 1988;25:237-43.

19 O'Brien AD, LaVeck GD, Thompson MR, Formal SB. Production of Shigella dysenteriae type 1like cytotoxin by Escherichia coli. $\mathcal{F}$ Infect Dis 1982;146:763-9.

20 Kavi J, Chant I, Maris M, Rose PE. Cytopathic effect of verotoxin on endothelial cells. Lancet $1987 ;$;i: 1035

21 Obrig TG, Del Vecchia PJ, Karmali MA, Petric M, Moran TR, Judge TK. Pathogenesis of haemolytic uraemic syndrome. Lancet 1987;ii:687.

22 Rose PE, Enayat SM, Sunderland R, Short PE, Williams CE, Hill FGH. Abnormalities of factor VIII related protein multimers in the haemolytic uraemic syndrome. Arch Dis Child 1984;59:1135-40

23 Rose PE, Armour JA, Williams CE, Hill FGH. Verotoxin and neuraminidase induced platelet aggregating activity in plasma: their possible role in the pathogenesis of the haemolytic uraemic syndrome. F Clin Pathol 1985;38:438-41.

\section{School refusal}

\section{Usually mild but sometimes severe}

About one 10th of all school pupils in Britain are absent at any one time, ${ }^{\prime}$ and a fifth of these have no legitimate reason for being away. ${ }^{2}$ Those absent without a legitimate reason fall into three main groups: truants, school refusers, and children voluntarily withheld by parents. Hersov compared 50 truants and 50 school refusers and showed that school refusers are more often passive, dependent, and overprotected and tend to come from families with a higher prevalence of neurosis. ${ }^{3}$ They generally work and behave well at school, and the refusal to go to school is a manifestation of a neurotic disorder in which anxiety and depression are prominent. Truants, in contrast, tend to come from larger families from which the father is often absent and to show a poorer standard of work and evidence of antisocial or delinquent behaviour. ${ }^{3}$ School refusal was first described in 1932 by Broadwin ${ }^{+}$and was later labelled "school phobia,"s but the term school phobia is now seen as an oversimplification because it pre-empts the question of whether the child is refusing to attend school (with a justifiable reason in a few cases) or refusing to leave home. ${ }^{6}$

School refusal has tended to be understood as primarily a consequence of separation anxiety, ${ }^{7}$ but Hersov says that "school refusal is not a true clinical entity with a uniform aetiology, psychopathology, course, prognosis, and treatment, but rather a collection of symptoms or a syndrome occurring against the background of a variety of psychiatric disorders." Accepting these limitations, he estimates that about $5 \%$ of all children referred for psychiatric help are school refusers. The condition tends to present in three peaks - at the ages of 5-7, 11 (associated with change of school), and 14 and older.

Up to four fifths of all children have difficulties in adjusting to primary school. ${ }^{9}$ Reluctance to attend school is thus a common problem largely dealt with by parents and teachers. Four fifths of general practitioners manage straightforward cases of persistent school non-attendance without referral. ${ }^{10}$
Many children present with somatic complaints such as abdominal pain, headache, and vague malaise," which require careful assessment to exclude an organic cause; the history may show precipitating factors such as changes in school or home or loss or illness of an important person.

Some children, however, may show such severe school refusal that residential care may be required. ${ }^{12}$ Defining school refusal as the association of a neurotic disorder with a reluctance to attend school for at least four weeks, Kolvin found that almost half of cases aged between 9 and 15 showed important depression. ${ }^{13}$ Assessment of depression is particularly important in adoiescents, and Shaffer's study of 30 successful suicides in children and young adolescents showed that four patients had originally presented with school refusal. ${ }^{1+}$ There is also a high incidence of depressive and anxiety disorders in first degree relatives of school refusers with severe symptoms ${ }^{15}$-almost half of the mothers in one study. ${ }^{16}$

Though the importance of the mother-child relationship has long been recognised, treatment is more effective when both parents participate ${ }^{17}$ and increased awareness of the importance of the father has led to a family centred approach. ${ }^{18}$ Successful treatment has been described using various approaches including psychoanalysis, ${ }^{19}$ behavioural therapy, ${ }^{20}$ cognitive-behavioural psychotherapy, ${ }^{21}$ and family therapy. ${ }^{22}$ It seems important that therapists using different approaches have identified two basic types of school refusala mild form with favourable prognosis and a severe form that is often resistant to treatment and associated with lack of parental cooperation..$^{23}$ The usefulness of drug treatment is still not clear, ${ }^{2+}$ and it should not be considered in general practice before referral. Generally, a child will return to school if parents and therapists use firmness and pressure, but a successful outcome cannot be equated solely with a return to school. A recent follow up over 15-20 years of 35 school 